\title{
What is Islam? The importance of being Islamic
}

\section{Pooyan Tamimi Arab}

To cite this article: Pooyan Tamimi Arab (2018): What is Islam? The importance of being Islamic, Material Religion, DOI: 10.1080/17432200.2017.1418224

To link to this article: https://doi.org/10.1080/17432200.2017.1418224

曲 Published online: 23 Feb 2018.

Submit your article to this journal $\pi$

III Article views: 86

Q View related articles $\sqsubset$

View Crossmark data $\nearrow$ 
book review 


\section{what is islam? the importance of being islamic}

Shahab Ahmed. 2016

Princeton: Princeton University Press

624 pp., ISBN 9780691164182

Reviewed by Pooyan Tamimi Arab

Utrecht University, the Netherlands

DOI: $10.1080 / 17432200.2017 .1418224$

(D) Check for updates

Some years ago, the late Muslim reformer Nasr Hamid Abu Zayd, who found refuge in the Netherlands, spoke with two exiled Iranian intellectuals about Islamic thought. They listened to his idea of interpreting the Qur'an in its proper historical context and extracting therefrom universal ethical truths. A fine proposal, to be sure, but "what about wine," one of them asked, as if this question determined their definitive evaluation of his suggestions, as if the proof of his Islam lay in his attitude towards drinking. "It is forbidden," Abu Zayd answered at first, then added "but not because of its properties in themselves, only due to an intoxicating effect." Smiling, he went one step further: "but ... I love red wine." For the two Iranians, themselves believing Muslims, there was the best proof of Abu Zayd's wisdom! They approved, not despite, but because of being Islamic. "I am one of those misunderstood Muslims," one of them recalled, meaning those who burst into joyous laughter when reading the greatest of the wine drinking Sufi-poets, Hafiz (fourteenth century AD). In What is Islam? The Importance of Being Islamic, Ahmed defends such a mode of being Islamic against the reduction of Islam to the Qur'an, Hadith and Law alone; in short, against the "legal-supremacist" trap, and beyond projects of Islamic reformation, by showing the explorative cosmopolitanism of Islam, its Weltoffenheit (open-mindedness).

This cosmopolitan mode of being is represented by the joint wisdom of Sufis and philosophers living in the Balkan-to-Bengal complex roughly between 1350 and 1850 . In this world, mystical and rational thinking often transcended the literalist interpretation of the text of the Qur'an, even going beyond distinctions of belief ( $d i n)$ and unbelief (kufr), beyond Islam as unambiguous piety or scripturalist correctness: "for philosophy and Sufism the Qur'an is of essence and nature and being not the highest (accessible) form of truth" (257, Ahmed's emphasis). He analyzes this thesis by looking at Islam as a human and historical phenomenon in which Ottomans, Persians, Mughals and others, from Sarajevo to Delhi, strived to move from the Seen to the Unseen through shared Islamic understandings and practices. They did so, according to Ahmed, mainly through poetry and philosophy, the so-called Sufi-philosophical (or philosophical-Sufi) amalgam, which was consistently underestimated in much of twentieth century and contemporary scholarship of Islam.

Central to Ahmed's reevaluation is the celebrated poetry of the Divan of Hafiz, which was,

in the period between the fifteenth and the late-nineteenth centuries, a pervasive poetical, conceptual and lexical presence in the discourse of educated Muslims in the vast geographical region extending from the Balkans through Anatolia, Iran and Central-Asia down and across Afghanistan and North India to the Bay of Bengal that was home to the absolute demographic majority of Muslims on the planet. (32)

And still today, even though Ahmed laments the loss of Persian among Asian Muslims outside Iran, Afghanistan, and Tajikistan - the reduction of a cosmopolitan tradition to modern, nationalist, ethno-linguistic boundaries-millions are attached to the poetry of Hafiz. Indeed, the mystical verse decorating the cover of a newly published Divan I acquired from Tehran, in 2017, leaves no doubt about the interpretive importance of Ahmed's notion of a Sufi-philosophical amalgam (Figure 1):

Who but Plato, jar sitter with wine, can reveal the mystery of wisdom to us again? (trans. Pooyan Tamimi Arab, based on older translations).

In these difficult to translate lines Plato is both a wise drinker as well as a metaphor for wine, which grants access to wisdom or philosophy (hikmat). Explaining such verses, Ahmed points out that a poet like Hafiz lived and thought in a world where Plato was known as Aflatun, a sage of Islamic thought in an Islamic world. Indeed, the poem goes on to glorify the wine jar as being worthy of circumambulation just like the Ka'bah, i.e. a Muslim practice. By doing so, Hafiz, a title for someone who has memorized the Qur'an, employed a shared field of Islamic references, a tradition that builds on and goes beyond the Holy Text by appealing to pre-textual, universal truths as well as to con-textualized interpretations of historical Muslims. The Qur'an thus becomes a basis for explorations that go beyond it:

Hafiz; drink wine, live in non-conforming-libertinage [rindi], be happy, but do not like others, make the Qur'an a snare of deception (trans. Ahmed, 37) 


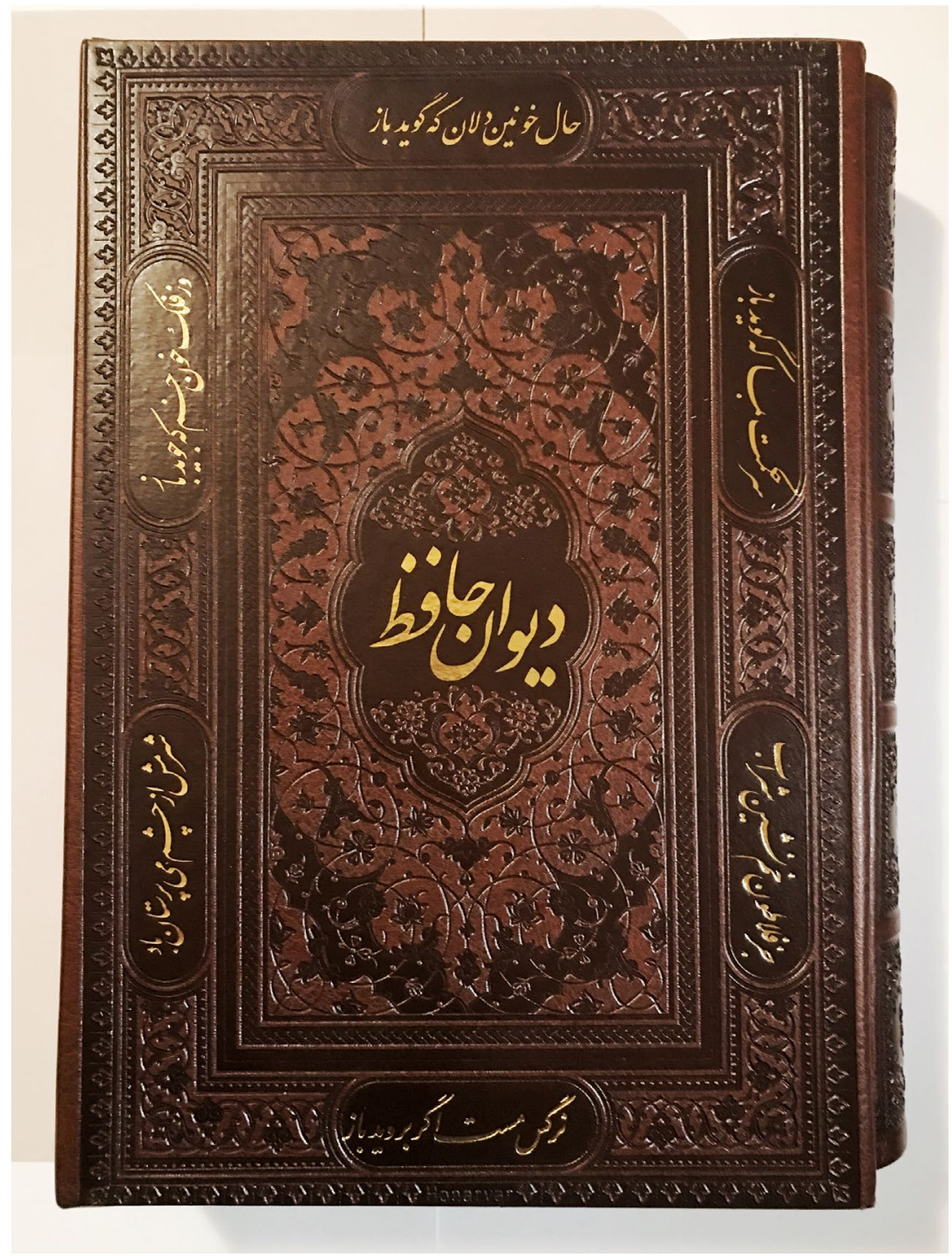

FIG 1

Cover of Divan of Hafiz, published in Tehran in 2016. Photograph by Pooyan Tamimi Arab.

In a devastatingly critical discussion of Clifford Geertz's Islam Observed, Ahmed does concur with the anthropologist on the centrality of meaning in any study of Islam: "Whatever and however differently Islam may mean to Muslims, to all Muslims Islam is meaningful" (249, Ahmed's emphasis). Combined with his extravagant polyglot erudition and extensive references to primary texts of Islamic poetry and philosophy, readers interested in Islamic materialities may find What is Islam? to succumb to the mentalistic fallacy of meaning as the primary, essential property of Islam and forms as its secondary, merely experiental expression. Ahmed can be interpreted as doing so in his discussions of wine drinking and figural painting, where these forms are explained as mediators between the Seen and the Unseen, from mere form to Meaning, from truth to Real-Truth (haqiqat). This is explicitly the case, for example, in his discussion of a miniature painted in Herat ca. 1430 when he cites the accompanying poetry, "Pass from the Figure, and go to the Meaning!" (413). The Arabic-Persian word for figure, surat, means face in its most basic meaning, so that from the face of things, we dive into the realm of divine meaning (ma'ni). And yet, it cannot be said that Ahmed simplistically reduces 
form to a secondary position, since such a reading would miss what is imperative to his analysis: that the distinction between real wine drinking and metaphorical, divine intoxicants cannot be drawn sharply. This is also seen in his references to the " $\mathrm{R}$ / real," "L/love" and "L/light," and described revealingly as the joint wisdom of the amalgam as "Sufi-philosophical-aesthetical" (44) and of "Hafiz-reciting aesthetes" (263, my emphases). "Wine is a means to meaning" (423), but nevertheless the relation of the material substance and Islam is, as a human and historical phenomenon, "mutually constitutive" (67, Ahmed's emphasis), a fusion of the "physical and imaginal senses" (32) which cannot be undone without semantic loss.

Throughout his 600-page magnum opus, sadly a posthumous publication, Ahmed refers to a variety of objects and material practices that are central to explaining his answer to the question of what Islam is, including Islamic music and dancing, the sartorial Sufi practice of crooked-hatted-ness (kajkulahi), and references to images of "people who wore flower-embroidered coats, and drank wine and indulged in dangerous liaisons of the heart" (202). This is perhaps best expressed in his magnificent analysis of a sixteenth-century miniature painting on display in the Metropolitan Museum of Art, the Allegory of Worldly and Otherworldly Drunkenness. Wine drinking, dancing and clapping, music and poetry, all are accounted for in this 11.5 inch tall Gesamtkunstwerk. Ahmed's analysis of high art is part and parcel of a broader interest in the "Islamic meaning of everyday things" and "The tactile and visual engagement with an ensemble of these objects in the performance of the actions of everyday life" (416), which mediate the movement from the Seen to the Unseen, from Form to Meaning, on daily basis.

These things are "discursive and physical artifacts" (514), objects which can function as "physical metaphor" (535). It is not possible to arrive at the question of what Islam is without them. Indeed, Ahmed writes about the above-mentioned allegory, which shows not only wine-drinking men but also angels, that the "painting is itself" (424) an answer to the question of what Islam is. It is a contradictory answer, given Islamic prohibitions of drinking and figure painting, and coherent given the shared appreciation of these works across a vast Islamic world as Islam. In other words, the object "itself" plays a crucial role in his conceptualization of the capaciousness of the adjective Islamic.

Ahmed's contribution does not lie in that there are Islamic materialities, of course, but that these objects can be better understood as the Islamic wine-bowls that they are, rather than divided by the modern categories of the secular, cultural, or religious.

No surprise then that the book's cover image is of a gold coin depicting the Mughal emperor Jahangir, holding a wine-cup in one hand and a book in the other; "one can only wonder which book!" (71). 